\title{
Ethnic armies and ethnic conflict in Burma
}

\section{Reconsidering the history of colonial militarization in the Kachin region of Burma during the Second World War ${ }^{1}$}

\author{
Mandy Sadan
}

\begin{abstract}
This paper considers the recruitment of volunteer levies into British forces in northern Burma during the Second World War. Using data compiled by a local veterans' association, the paper raises questions about the supposed historical continuities that are believed to exist across military forces of the pre- and post-war periods. The data indicate that prevailing assumptions about the motivations and aspirations of local recruits should be challenged more than they have been to date. The author proposes new approaches to using quantitative data to reveal broader social trends in issues of military recruitment that could be extended into other times and places. Such methods could be particularly helpful in facilitating deeper and more nuanced demographic and social insights into Burma's history of internal militarized conflict and the ways in which recruitment practices relate to the communities from which recruits are drawn.
\end{abstract}

Keywords: soldiers; Kachin; Second World War; Burma

Author details: Dr Mandy Sadan is Lecturer in the History of South East Asia at SOAS, Thornhaugh Street, Russell Square, London WC1H 0XG, UK. E-mail: ms114@soas.ac.uk.

\section{Background}

While many British imperial structures could be accused of fatally compromising the cohesion of the independent Burmese state, the military has attracted some of

I am delighted to dedicate this paper to Professor Ian Brown. He was the most supportive of $\mathrm{PhD}$ supervisors, and was an inspiration in the uncomplicated humanity of his approach combined with an uncompromising demand for intellectual rigour. For all of his insights and support over many years, I am greatly indebted to him. In producing this research, I am very grateful to Lt Colonel Sam Pope, who was at this time Secretary of the Burma Forces Welfare Association, Hkanhpa Tu Sadan and the continued hard work of CC Naw Ja. Thanks also to Captain Hkun Seng, Lt Nhkum La and Major Gum Ja Naw. Vicky Bowman and the staff of the British Embassy in Yangon were extremely helpful in facilitating communications and providing support at different times. Thanks also to Sherry Scott and others in the BFWA for their ongoing endeavours, as well as Bellay Htoo South, who developed a recording project among former Karen recruits among whom assistance was distributed. The work of Sally Steen in initiating these reconnections was critical for everyone concerned. My thanks also go to the anonymous reviewers of this article. The article is partly intended to provide additional quantitative data on an issue that is dealt with qualitatively in M. Sadan (2013), Being and Becoming Kachin: Histories Beyond the State in the Borderworlds of Burma, The British Academy and Oxford University Press, Oxford. 
the most universal criticism. ${ }^{2}$ The crisis within the Burman heartland brought about by colonial rule was profound, and the apparently anti-Burman orientation of the army was a potent symbol of this experience. ${ }^{3}$ Military structures acted as a lightning rod for the oppression felt by Burmese nationalists, who felt marginalized within their own country, partly through their apparent exclusion from the colonial army. ${ }^{4}$ Figures such as Legislative Council member U Aung Gyi felt that the differentiated recruitment of Burman versus non-Burman 'ethnic' soldiers represented the worst kind of anti-Burman colonial racial prejudice, which nationalists now had to challenge by independently re-militarizing themselves. ${ }^{5}$ Perceived as 'divide and rule' in practice, this policy has subsequently been blamed for exacerbating or even creating militarized divisions in the Union of Burma after 1948. ${ }^{6}$ While there are many seeds of truth in this argument, this paper hopes to raise new questions about these issues. It hopes to challenge some of the assumptions that have dominated discussions of the colonial military and the relationship it had with its 'ethnic' recruits. It aims to make this appear a subject that could be fruitful for further research, rather than a historical question about which we already know the 'big' answers and about which detailed research cannot now be conducted. The paper also suggests a methodological approach that could be extended fruitfully for exploring comparative situations both in and beyond Burma.

As discussions turned to the creation of an independent state after the Second World War, the problem of what to do about the army became a critical focus of discussion in its own right, as soldier-politicians grappled with their discomforting inheritance. The colonial military had mainly recruited 'martial races', ${ }^{7}$ and leaders of the new Burma National Army believed that 'ethnic' soldiers would

There have been a number of significant and insightful critiques of militarism in Burma from a historical perspective, including Mary P. Callahan (2003), Making Enemies: War and State Building in Burma, Cornell University Press, Ithaca, NY; R.H. Taylor (2006), 'Colonial forces in British Burma: a national army postponed', in K. Hack and T. Rettig, eds, Colonial Armies in Southeast Asia, Routledge, London and New York; Maung Aung-Myoe (2009), Building the Tatmadaw: Myanmar Armed Forces Since 1948, Institute of Southeast Asian Studies, Singapore; A. Selth (1986), 'Race and resistance in Burma, 1942-45', Modern Asian Studies, Vol 20, No 3; M. Smith (1989), 'Burma and World War 2', Cultural Survival Quarterly, Vol 4, No 13; Martin T. Smith (1999), Burma: Insurgency and the Politics of Ethnicity, Zed Books, London.

Taylor, supra note 2; Kei Nemoto (2000), 'The concepts of Dobama ("our Burma") and ThudoBama ("their Burma") in Burmese nationalism, 1930-48', Journal of Burma Studies, Vol 5; Selth, supra note 2 .

4 This was also experienced through the sense of political and economic exclusion that focused upon the large-scale movement of migrants from India and perceived economic disparities in dealing with Chinese business networks. This resulted in some significant race riots throughout the 1920s and 30s. Ian Brown (2005), A Colonial Economy in Crisis: Burma's Rice Delta and the World Depression of the 1930s, RoutledgeCurzon, London and New York; Michael Adas (1974), The Burma Delta: Economic Development and Social Change on an Asian Rice Frontier, 18521941, University of Wisconsin Press, Madison, WI; David Steinberg (2010), Burma/Myanmar: What Everyone Needs to Know, Oxford University Press, Oxford and New York.

Callahan, supra note 2, at p 37. He formed his own Tat or equivalent of a private militia in 1930. This is particularly the case in the large amount of material produced by organizations and individuals with a political science, development studies and/or international relations orientation, which tend to rely very heavily on a limited number of secondary sources when framing the historical context against which to develop their more contemporary analysis. This is so habitual that it seems unfair to highlight any one piece of work as an exemplar of this trait. It is, of course, an outcome of the relatively small amount of historical research undertaken on these issues.

The development of this policy was in many ways more accidental than rigorously thought through. It also related to military policy issues beyond Burma and was not a purely local characteristic. See Sadan, supra note 1; H. Streets (2004), Martial Races: The Military, Race and Masculinity in British Imperial Culture, 1857-1914, Manchester University Press, Manchester and New York. 
have questionable loyalties to the new Burmese state. The war had made these military ruptures along ethnic and racial lines even deeper. ${ }^{8}$ The Burma Independence Army had supported the invading Japanese troops and had fought against those men affiliated with colonial forces. Subsequently, the leaders of the Burma National Army made no secret of their strategic realignment with Allied powers in the cause only of gaining independence for Burma more quickly, often with little regard for the concerns of 'ethnic' constituencies. ${ }^{9}$ Building an army to defend the new nation, therefore, meant having to deal directly with the ethno-racial military divisions that British imperialism and war had bequeathed. ${ }^{10}$ Mary Callahan has shown how the weak, newly independent state was incapable of preventing the continuation of these allegiances following the remodelling of the national army along lines similar to those of colonial forces after the Second World War. ${ }^{11}$ This had been decided in the Kandy Agreement of 1945 between General Aung San and Lord Mountbatten, which reconstituted the Burma Army with ethnic class divisions. ${ }^{12}$ The cohesion of the country's new national army appeared to have been compromised from the outset because of the unwelcome colonial military legacy from which it seemed impossible entirely to shake free.

Following independence, multiple problems and structural failings undermined the new state and contributed to the emergence of widespread armed revolts against the central government. ${ }^{13}$ These revolts were both internally and externally driven, and not least of the influences upon their manifestation was the violence that erupted in China following the communist revolution and the unfolding of Cold War politics across the region. ${ }^{14}$ The colonial army remained a potent symbol for Burman nationalists in this situation. When national politicians and military leaders recalled the prejudice endemic in the colonial military system, it was to remind Burmese people that they should feel pride in their new national army, the Tatmadaw, as their liberator from oppression. ${ }^{15}$ However, the damning legacy of colonial divisions seemed most acute and pertinent when explaining why the Union should be descending so rapidly into chaos. The emergence of ethnically framed armed groups seemed more irrational than rational to Burmese politicians and public alike. ${ }^{16}$ These were complex issues with complex origins. Many of these conflicts

\section{Callahan, supra note 2.}

Smith (1989), supra note 2.

10 This of course included the history of separate administrative areas described as 'Scheduled and Excluded Areas'. Michael Aung-Thwin (1985), 'The British "pacification” of Burma: order without meaning', Journal of Southeast Asian Studies, Vol 16, No 2; Michael W. Charney (2009), A History of Modern Burma, Cambridge University Press, Cambridge; Smith (1999), supra note 2; M. Walton (2008), 'Ethnicity, conflict and history in Burma: the myths of Panglong', Asian Survey, Vol 48, No 6.

11 Callahan, supra note 2.

12 R.H. Taylor (1987), The State in Burma, C. Hurst, London.

13 Charney, supra note 10; Smith (1999), supra note 2; Steinberg, supra note 4; R.H. Taylor (1982), 'Perceptions of ethnicity in the politics of Burma', Southeast Asian Journal of Social Sciences, Vol 10, No 1; Taylor, supra note 12.

14 Bertil Lintner (1990), The Rise and Fall of the Communist Party of Burma (CPB), Southeast Asia Program, Cornell University, Ithaca, NY; R.H. Taylor (1973), Foreign and Domestic Consequences of the KMT Intervention in Burma, Southeast Asia Program, Cornell University, Ithaca, NY.

15 Nemoto, supra note 3. This was not an issue exclusive to Burma. See K. Hack and T. Rettig, eds (2006), Colonial Armies in Southeast Asia, RoutledgeCurzon, London.

16 For an interesting critique of this in a related contemporary context, see M. Walton (2013), 'The "wages of Burman-ness": ethnicity and Burman privilege in contemporary Myanmar', Journal of Contemporary Asia, Vol 43, No 1. 
were not entirely or even mainly ethnic in nature, but they were rationalized along ethnic and racial lines. ${ }^{17}$ Some of the new non-national 'ethnic' armies were notable for their size, ability to organize and to fight the Burma Army on its own terms. Of these groups, the Karen National Defence Organization (KNDO, formed in 1947) and the Kachin Independence Army (KIA, formed in 1961) went on to present some of the most significant challenges to Tatmadaw military hegemony. ${ }^{18}$ These were military organizations capable of producing parallel civil-military infrastructures in the territories under their control, and in many ways acted as alternative systems of local governance. ${ }^{19}$ In this respect, mapping the origins of these armies on to the ethnic class-based structures of the colonial military appeared reasonable, even obvious. Historically, both Karen and Kachin ethnic constituencies had seemed particularly privileged within the colonial military system. The logistical and technological capacity of these new, hyper-inflated ethnic armies could surely only have been nurtured in the colonial military nursery. In addition, although neither of these armed groups was defined by religious beliefs, they both became allied with social ideologies of Christian-oriented ethno-nationalism during years of conflict. ${ }^{20}$ This added weight to the perceptions of avowedly Buddhist politicians such as Prime Minister $\mathrm{U} \mathrm{Nu}$ that these groups were the tangible legacy in the present of differentiated colonial practices in the past; a similar argument was used by the military regime under General Ne Win as it promoted the ideology of the Burmese Way to Socialism. ${ }^{21}$ In this way, the origins of these two non-national armed groups in particular did not need to be understood deeply in the public or even the political sphere. This kind of historical stereotyping became more rooted as the propaganda machine of the Burmese military became fully established after $1963 .^{22}$

In some respects, the historical association made between these forces seems reasonable, which is why it has been persuasive for so many. However, in

17 A strong economic history of ethnic conflicts in Burma has yet to be written. For some initial insights into these issues in a Kachin historical context, see Sadan, supra note 1.

18 Ashley South (2008), Ethnic Politics in Burma: States of Conflict, Routledge, Abingdon; Ashley South (2011), Burma's Longest War: Anatomy of the Karen Conflict, Transnational Institute/ Burma Centre Netherlands, Amsterdam: Ardeth Maung Thawnghmung (2011), Beyond Armed Resistance: Ethnonational Politics in Burma (Myanmar), Policy Studies No 62, East-West Centre, Honolulu, HI.

19 Ardeth Maung Thawnghmung (2008), The Karen Revolution in Burma: Diverse Voices, Uncertain Ends, Institute of Southeast Asian Studies, Singapore; Tom Kramer (2007), The United Wa State Party: Narco-Army or Ethnic Nationalist Party? East-West Center, Washington, DC, and the Institute of Southeast Asian Studies, Singapore; M. Sadan (2009), 'Ethnic minorities and political governance: the Myanmar situation', in L. Ghosh, ed, Minorities, Community Rights and Political Governance: South \& S.E Asian Scenario, Routledge, Abingdon; Ashley South (2003), Mon Nationalism and Civil War in Burma: The Golden Sheldrake, RoutledgeCurzon, London.

20 Ashley South (2007), 'Karen nationalist communities: the "problem” of diversity', Contemporary Southeast Asia, Vol 29, No 1; Sadan, supra note 1.

21 For an academic reinterpretation along these lines, see Taylor, supra note 13, which was an important article when initially published for challenging the reification of ethnic problems. See Steinberg, supra note 4 for an overview of the historical context of these regimes, and I. Jordt (2007), Burma's Mass Lay Meditation Movement: Buddhism and the Cultural Construction of Power, Ohio University Press, Athens, OH, for a broader discussion of the cultural role of Buddhism.

22 For some attempts to break down the simplifications of these representations, see M. Sadan (2007), 'Decolonizing Kachin: ethnic diversity and the making of an ethnic category', in M. Gravers, ed, Exploring Ethnic Diversity in Burma, NIAS Press, Copenhagen; South, supra note 20; Thawnghmung, supra note 18; and Thawnghmung, supra note 19. 
acknowledging this, it is important to recognize that the perception was driven more by assumptions and emotion than by detailed research, and it has largely remained so. This linear narrative provided a way of imagining in a simple, accessible way the otherwise complex historical roots of post-colonial ethnic problems in Burma. However, it has also been accepted in much academic writing on these issues, though arising from rather more convoluted roots and with interpretations that are sometimes more sympathetic to the interests of ethnic communities. ${ }^{23}$ Robert Taylor has written most fully about the colonial army and its influence on Burmese nationalism. ${ }^{24}$ His analysis is important for detailing how the sense of Burman exclusion led to the creation of Burman non-state, nationalist armed militias between the two World Wars. ${ }^{25}$ Yet his sensitivity to this historical dynamic is not matched by sensitivity to that of 'ethnic' soldiers as colonial associates. As such, his account reveals some of the stereotypes that circulate within a nationalist, Burman-centred framework of analysis. Taylor states, for example (with emphasis added):

'The explicitly discriminatory policy of the British in developing colonial armed forces in Myanmar led to a number of differing responses. Among the Karen, Chin and Kachin communities, from whom the British positively encouraged recruitment, a degree of loyalty to Britain and pride in colonial military service developed. This was demonstrated by the loyalty of many of these troops during the Second World War when they remained loyal to Britain in defeat.... The loyalty of the minority communities was enhanced because many of them became Christian. Military service and missionary activities became routes to modernity and social advancement for young men from what had been previously extremely poor and politically unsophisticated communities. ${ }^{26}$

\section{He concludes that:}

'An army postponed does not necessarily result in an army denied and the Burma army that governs the country today is the direct descendent of the Burmese nationalist force that the British forestalled. Many of their armed opponents, particularly in the Karen National Union, have their mythical origins in the distant past of the first British Burma Army.'27

All of these statements could be questioned. ${ }^{28}$ One outcome of these stereotypes, however, has been that Kachin and Karen colonial recruits in particular have come to represent not the socially complex demographic categories that in fact they were, but rather the politically and ideologically immature embodiments of their

23 Among those seeking to display a more sympathetic understanding of issues from the 'ethnic' side there has been a tendency to use the interpretations of historical missionaries in the region in a more uncritical way than might be expected. The best example of this in the Kachin case is the apparently ubiquitous referencing of H.G. Tegenfeldt (1974), A Century of Growth: The Kachin Baptist Church of Burma, William Carey Library, South Pasadena, CA and the data he supplies showing a dramatic increase in the number of Christian converts in the region before the war. See Sadan, supra note 1 for a reinterpretation of this material.

24 Taylor, supra note 2, at pp 195-209.

25 Ibid.

26 Ibid, p 201.

$27 \quad$ Ibid, p 207.

28 For which see Sadan, supra note 1. 
respective 'ethnic groups'. They perpetuated the erroneous constructions of the colonial state in their aspirations, their martiality and opposition to Burmese nationalism, and latterly towards the independent Burmese state itself. Loyal to colonialism and having a primitive tendency towards violence combined with a large dose of political naivety, the colonial military experience provided them with the knowledge base from which they could endlessly reproduce militarized organizations to oppose the Burmese state in the longer term. In this way, the notion that the colonial military encounter buttressed - indeed, continues to buttress - their opposition has become one of the most frequently repeated historical representations of how the malign historical influence of 'divide and rule' continues to undermine political cohesion in the Burmese state today.

\section{A problem with no solutions?}

In raising hopes that new insights into these complex issues may emerge, one must question whether detailed research could even be developed today. So many years after the fact, time becomes a problem in this context, as clearly the number of people still living who might have direct experience of serving in colonial forces is bound to be small and rapidly diminishing. ${ }^{29}$ In addition, social disruption over the long term and mistrust of making oneself vulnerable to individual observation and critique after decades of political repression are likely to obstruct the smooth development of any research programme into these still-sensitive issues. There are, of course, many colonial military sources that can be explored with some interest,,$^{30}$ but these provide limited insights into how experiences of local recruits in one armed force might have influenced histories beyond it. These sources also lack detail when it comes to illuminating the lives of the largely anonymous band of men we call Kachin soldiers or Karen soldiers. ${ }^{31}$ The apparently closed nature of the intellectual world in which these accounts were produced renders them impervious to the study of local experience or subjectivities. ${ }^{32}$ Although

Of the 1,106 records used in this research, $746(67.45 \%)$ were of men born in 1920-29. Those born in 1920 would have been 82-86 years old. However, please see later comments on the transmission of these data by spouses. See Sadan, supra note 1 for discussion of the political dynamics affecting young people born in the 1920 s.

30 The European Manuscripts Collections of the India Office Collections in the British Library hold some of these records, but see also works such as Ian Fellowes-Gordon (1958), Amiable Assassins, Hamilton, London; Ian Fellowes-Gordon (1971), The Battle for Naw Seng's Kingdom: General Stilwell's North Burma Campaign and its Aftermath, Cooper, London. Recently this has been extended to compiling more personal narratives, such as in Julian Thompson (2009), Forgotten Voices of Burma: The Second World War's Forgotten Conflict, Ebury Press in association with the Imperial War Museum, London.

31 The official files of the Indian Army in the British Library contain a good deal of information about recruitment in Burma and the logistics of militarism, through a number of different series such as L/Mil and the various Burma Office Files in later periods. There have also been disappointments for local researchers from these communities when the nature of some of these materials has been made known to them. Often, local researchers anticipate that detailed histories of key local historical figures in the colonial forces will be contained within official military records. This is invariably not the case. Findings are from a Workshop on Historical Research Methods with local researchers held on the Burma-China border in February 2002, supported by funds from the Burma Project of the Open Society Institute, the James Green Trust, SOAS Research Committee and funds from the University of London Research Committee.

32 For discussion about re-reading such materials, see Ann Laura Stoler (2009), Along the Archival Grain: Epistemic Anxieties and Colonial Commonsense, Princeton University Press, Princeton, NJ. 
the personal accounts of former Allied soldiers about their wartime experiences are more numerous, the records of the machine itself seem uncompromisingly resistant to helping us understand the histories of ordinary local recruits drawn into the imperial military world system; this was, of course, always its intent. One might reasonably question, therefore, whether it is still possible to generate new understandings of these issues locally. However, in recent years the gradual opening up of the country to foreign visitors has led to the emergence of some new data. ${ }^{33}$ This paper will focus on the material that has emerged from the Kachin region.

Understanding of the military heritage of the Kachin region has been a focus of local interest in recent years. ${ }^{34}$ Jinghpaw language books and pamphlets have been published to honour military figures in the colonial army, from both before and during the Second World War. ${ }^{35}$ However, this also coincided with reconnections being made between former soldiers in the Karen and Kachin regions with the Royal Commonwealth Ex-Services League and other veterans' organizations. ${ }^{36}$ Myitkyina was known intimately to many foreign servicemen, as the town was a vital part of Allied strategy over 'The Hump' between India and China. ${ }^{37}$ Following the partial opening up of tourist travel to Myanmar in the mid-late 1990s, some former soldiers returned to the town for the first time since the war. They became aware that many former volunteers in Allied forces were still alive, although often impoverished and in need of medical and other support. Some of the US and British servicemen felt they owed a debt of gratitude to these wartime colleagues, who had no entitlement to a pension or financial support from any government. ${ }^{38}$ They could empathize with them now about the challenges that an ageing body could bring, whereas previously they had shared the youthful experience of bombs, starvation and fear. ${ }^{39}$ In the UK, it was decided to found an organization called the Burma Forces Welfare Association (BFWA), which would

33 Following 'Visit Myanmar Year' in 1996-97, it became possible for foreign tourists to enter the country for up to one month. Limited travel to towns such as Myitkyina became viable, although visitors were frequently observed and their activities reported to the local authorities.

34 Discussing the complexities of this is beyond the scope of this paper, but further information may be obtained from M. Sadan (2007), 'Historical photography in Kachin state: an update on the James Green Collection of photographs', South Asia: The Journal of the South Asia Studies Association of Australia, Special Issue: Northeast and Beyond: Culture and Change.

35 Bhamo Army and Military Pensioners Ex Servicemen's Association, Jinghpaw Hpyen Dap Laba Laika (place and publisher unknown; date unknown); Nawng Ba and Myithtoi Hpauyu, Gam Awng (2001), Mungkan Chyam Ai Jinghpaw Hpyen La Mazut Ni Mesopotamia (1917-19), May Offset, Yangon; Gam Awng Myihtoi (2000), Subedar Major Myihtoi Naw a Ahtik Labau (place and publisher unknown). These are just some of the local publications of this kind circulated around this time.

36 Sally Steen is credited with doing much to initiate this new awareness through her activities in the Karen region and in alerting the Royal Commonwealth Ex-Services League, out of which the Burma Forces Welfare Association was established. She has subsequently set up the charity Hope 4 Forgotten Allies. On the US side, there have been parallel efforts to make reconnections with former volunteers in US organizations.

37 Fellowes-Gordon (1971), supra note 30, during the effort to force Japanese troops out of Burma and China. A good general account of the wartime experience of the region as a whole is C.A. Bayly and T. Harper (2007), Forgotten Wars: The End of Britain's Asian Empire, Allen Lane, London.

38 Similar discourses have of course been played out in the UK in relation to Gurkha entitlements of various kinds, which have attracted a lot of publicity in recent years. See website: http:// www.gurkhajustice.org.uk/.

39 For a historical account of the relationships between these forces in this region, see FellowesGordon (1971), supra note 30. 
raise money to distribute small stipends to those who could demonstrate that they had fought with British forces..$^{40}$ In order to facilitate these linkages and control the distribution of stipends, a local research group was formed in Myitkyina, called the Kachin Veterans Committee. The Committee was responsible for identifying individuals active with British forces and verifying their claims. It was because of this reconnection that the data used in this paper were created.

Initially, the local researchers set about trying to identify as many former wartime volunteers as possible. At first they produced qualitative data, focusing on well known figures around Myitkyina whom it was known had fought alongside Allied forces. They submitted a letter in English outlining their military engagements, provided copies of supporting documentation and a photograph, if available. However, it became apparent that they would have to modify this approach, as the number of people coming forward soon became too large to deal with in this way. In addition, the BFWA needed data that would validate the claim concerning the individual's connection and role, rather than that which expanded upon their subjective experience. ${ }^{41}$ They therefore adopted the standard form used by the Royal Commonwealth Ex-Services League for such purposes. Understanding the ways in which this form operationalized key concepts in the project is important when using the material as a secondary dataset, as in this paper.

First, the concept Kachin had to be operationalized. ${ }^{42}$ This was dealt with as a nominal measurement, exclusive and homogeneous, without any subcategories. This might surprise those familiar with the category 'Kachin' as an umbrella for a number of subgroups, notably the Jinghpaw, Zaiwa, Lisu, Nung or Rawang, Lachik or Lawngwaw. The form made no distinction for constructs of lineage other than that of the 'surname', which researchers interpreted through the main lineagefamily segment of the individual. Neither was the variable of religious affiliation included: the essential purpose was to establish an external connection for the target population group, and the nominal measurement Kachin was adequate for this purpose. In daily life, subgroup affiliation has limited influence in daily communications, as it is the kinship system, constructed to operate across subgroups, which determines the form of address and other forms of interaction, so it is not certain that a locally developed form would have framed this concept differently. ${ }^{43}$ However, for those seeking to pursue distinctions in relation to the concept Kachin in the data at a secondary level, there are some opportunities for doing so, but they should be approached with caution. It is possible to delineate subgroup identities through the names of families and lineages detailed in the data. They do not always map neatly on to subgroups; although true more often than not, convergence can

40 This would typically be between $£ 30$ and $£ 300$, usually as a once-only payment, although further requests for support could be made in cases of severe hardship. As the number of people eligible to receive support increased, this put pressure on BFWA funds, leading to most grants being made towards the lower end of this range. American servicemen established other local development projects too.

41 Researchers worked on a voluntary basis and their research method was developed locally.

42 For a more complete analysis of the historical and societal complexities of this term, see Sadan, supra note 1.

43 Ibid. See also Edmund Leach (1970), Political Systems of Highland Burma: A Study of Kachin Social Structure, Athlone Press, London; Edmund Leach (1961), Rethinking Anthropology, Athlone Press, London; La Raw Maran (2008), 'The continuing relevance of E.R. Leach's Political Systems of Highland Burma to Kachin Studies', in F. Robinne, and M. Sadan, eds, Social Dynamics in the Highlands of Southeast Asia: Reconsidering Political Systems of Highland Burma by E.R. Leach, Brill, Leiden. 
not always be assumed, which could affect results. ${ }^{44}$ In addition, there was a tendency in colonial forces for non-Jinghpaw recruits to adopt Jinghpaw names. ${ }^{45}$ This may have produced a bias towards Jinghpaw nomenclature in the target population group, although this is untested in the data sample. The concept Kachin, therefore, seems to have reflected one of two social realities for the researchers. Either the individual had been incorporated by ethnic class-based organizations that were deemed to be Kachin in name or primary composition (85th Burma Rifles, Northern Kachin Levies, 1st Kachin Rifles, and so on), or they were incorporated into forces that might be wider in ethnic make-up (Bhamo Military Police, for example), but the individual had self-identified as Kachin. There is little evidence that non-Kachin-identifying individuals in these organizations were brought into the research network on any scale, even though the BFWA would have made no distinction in this regard. ${ }^{46}$ Therefore, the operationalization of the concept Kachin in this project incorporated mainly those who remained within a Jinghpawlanguage nexus (although not just a Jinghpaw-lineage nexus). However, in this case, the findings are even more challenging to simplistic discourses about the development of Kachin ethno-nationalism across militarized groups. ${ }^{47}$ Future research intending to extend the variables of this concept along subgroup and segment lines might be best advised to focus on qualitative enquiries around the various sites of enlistment during the Second World War ${ }^{48}$ to understand localized experiences of militarization and conflict. ${ }^{49}$ To extend an analysis of this kind qualitatively would require an approach more consistent with the study of village networks proposed and developed by François Robinne. ${ }^{50}$ For the purposes of this exploratory secondary research, therefore, the concept Kachin has been used as operationalized by local researchers.

44 The data sample is striking for the very wide range of lineages that seem to have been incorporated, with those typically associated with the Yunnan borderlands all the way through to the northern reaches, as one might expect. This reflects the rigour with which the research was carried out and the extensive travelling that was undertaken.

45 See Sadan, supra note 1 for discussion of this and other aspects of the culture of militarization.

46 Fewer than 10 names appear to be Shan or Burmese in origin, and most of these relate to recruits into the Shan Battalions. These data need to be used cautiously.

47 For a brief discussion of some of the individual 'discrepancies' in such personal histories, see Sadan, supra note 1 . Because of the ethical issues implicated in secondary use of this dataset, the individuals have been given pseudonyms.

48 Edmund Leach was active in military recruitment during the war. See Stanley Jeyaraja Tambiah (2002), Edmund Leach: An Anthropological Life, Cambridge University Press, Cambridge. However, the most detailed research conducted on this aspect of Leach's life has been undertaken by Professor Robert Anderson, whose work on Leach is greatly anticipated. Some initial findings have been published as R. Anderson (2007), 'The biographical origins of Political Systems of Highland Burma', in F. Robinne and M. Sadan, eds, Social Dynamics in the Highlands of Southeast Asia: Reconsidering Political Systems of Highland Burma by E.R. Leach, Brill, Leiden. My thanks to Professor Anderson for his continued support of this and related research activities over many years.

49 This will not form part of this research paper, but is an ongoing focus of enquiry. Sometimes recruits would travel long distances to reach these sites and were not, therefore, always 'local'. The sites identified for both enlistment and de-enlistment are numerous and widespread, with 70 categories in the first variable and 72 in the second across the whole data sample, that is: not just during the Second World War.

50 C. Culas and F. Robinne, eds (2010), Inter-Ethnic Dynamics in Asia: Considering the Other through Ethnonyms, Territories and Ritual, Routledge, London; F. Robinne, and M. Sadan (2007), 'Reconsidering the dynamics of ethnicity through Foucault's concept of "spaces of dispersion"”, in F. Robinne and M. Sadan, eds, Social Dynamics in the Highlands of Southeast Asia: Reconsidering Political Systems of Highland Burma by E.R. Leach, Brill, Leiden. 
The second concept was active association with British military organizations. In contrast, this variable encompassed a very wide range of categories as it became clear that association with British military forces could apply to the periods both before and after the Second World War with equal justification. Indeed, the service histories of the individuals in the dataset revealed considerable complexity as some men moved between different organizations, sometimes over very extended periods. ${ }^{51}$ This led to a more extensive accounting of the different organizations with which individuals had been associated. As the research period drew to a close and fewer people came forward, porters, elephant handlers and others started to appear among the claimants. This led to questions about the boundaries of the concept, as it was felt that those who warranted inclusion and who could be identified had probably already been so. This variable overall, however, has been a rich one for secondary research, although again, the data have had to be used cautiously as recording was not always systematic. For example, sometimes the company of the Northern Kachin Levies ('A' Coy, 'B' Coy, and so on) was listed, and sometimes it was not, perhaps because it was not known, rather than because it was simply omitted. The recruitment data have therefore been recoded in this secondary research to make them more usable. The dates of enlistment and dates of demobilization for each individual have been recoded as spans of time, determined by meaningful phases in relation to colonial military structures (see Figure 3). By recoding, it was possible to identify whether an individual had enlisted before, during or after the Second World War and to group these individuals together. In this way, the delineation of variables relating to the concept active association with British military organizations became an effective way of tracing the trajectory of military careers within the population sample across a range of different time periods, which is the primary question addressed in this paper.

The final concept was whether the claim for assistance was being made on behalf of the soldier himself (occasionally herself, in relation to nursing auxiliaries) or the widow (or widower). Unsurprisingly, many former soldiers and volunteers had long since passed away, but the BFWA was prepared to pay stipends to the still-surviving widows or widowers. ${ }^{52}$ This was to prove critical to the success of the project. In addition to the fact that women tend to marry at a slightly younger age than their husbands, there is a cultural tendency for men in this region, and certainly of this generation, to remarry upon the death of a spouse, as it is believed to be very undesirable to be left alone as a widower. ${ }^{53}$ The number of female spouses eligible for grants, therefore, was very large relative to the group. Indeed, $66.58 \%$ of those providing information and obtaining stipends were widows. The information they provided extended the range of data about the target

51 See Sadan, supra note 1 for some detailed examples.

52 The film Burma Victory shows footage of the field hospital in Myitkyina with local nurses. Produced originally by the British Army Film Unit and Directed by Roy Boulting, it has recently (in 2005) been republished as Burma Victory: The Forgotten War, Imperial War Museum Official Collection, Imperial War Museum, London.

53 Appreciation of the wider cultural dynamics of this belief in a Jinghpaw context was developed during research into ritual language traditions during 1996-99 in Burma. See Sadan, supra note 1; M. Sadan (2012), 'Cords and connections: ritual and spatial integration in the Jinghpaw Cultural Zone', in T. Blackburn and S. Huber, eds, Origins and Migrations in the Extended Eastern Himalayas, Brill, Leiden. 


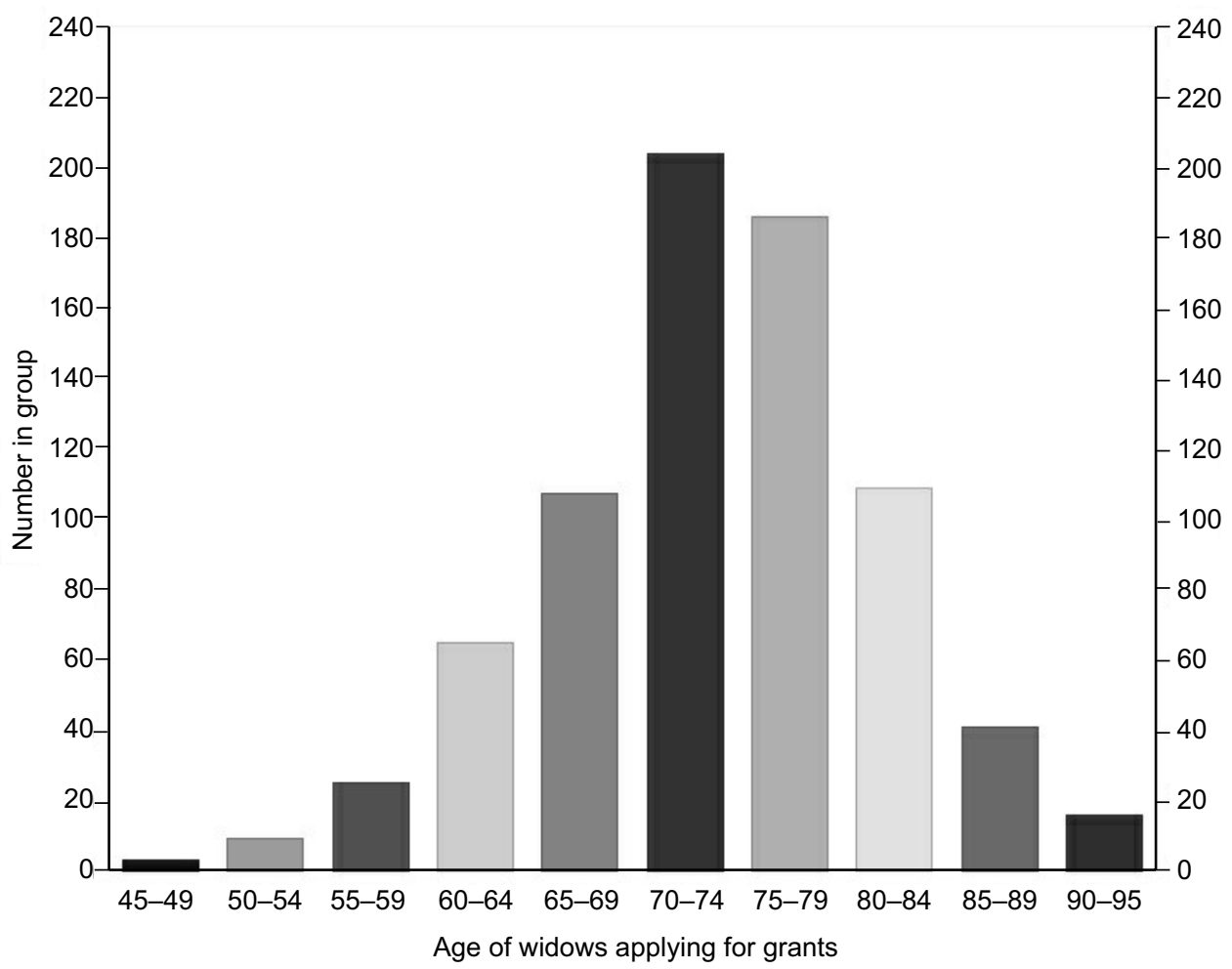

Figure 1. Age of widows applying for grants by group.

population significantly. The oldest widow (whose husband first enlisted in the Burma Rifles in 1925) was 104 years old, and the youngest was 38 . However, the trimmed mean age of the widows ${ }^{54}$ when they applied for the grants was 73.28 years old (see Figure 1). In many respects, therefore, this should be considered a women's project, as it was largely the women of the region who were responsible for passing on these histories. This is a dynamic that requires serious study in its own right, although it lies beyond the scope of this paper. ${ }^{55}$ Further potential in this regard is given by the fact that operationalizing the concept of spousal entitlement meant validating spousal relationships. This resulted in detailed data being collected about the age of the spouse, the date at which the husband or wife died, the number of children and their dates of birth. These data could prove useful for more socially orientated secondary research in which quantitative social histories about family size might be considered, although such a study lies beyond the scope of this paper.

The data form, therefore, collected the following information: date of birth, date of enlistment, date of de-enlistment, place of enlistment, place of de-enlist-

54 All those 48-94 years old $=99.73 \%$ of the total for whom there are age data.

55 It is notable that subsequently, women were mentioned barely at all in the related volumes that were produced, although the research did result in the founding of a Women's Volunteer Group as well. For discussion of how some of these issues relating to gender and martiality are played out in different contexts, see S. Dudink, K. Hagenamm and J. Tosh, eds (2004), Masculinities in Politics and War: Gendering Modern History, Manchester University Press, Manchester. 
ment relating to the person upon whom eligibility for the grant was to be assessed; name and date of birth of the person making the application where that was different (for example, a widow); details of the names, ages and gender of family members within the immediate household (spouses, sons and daughters only). The main researcher, with some occasional assistance, worked for more than four years in the period 2001-06 in Myitkyina and its outskirts, in Mogaung, Shwegu, Yangon, Mai Ja Yang and in the environs of Sumprabum to identify all those who were still alive and had been incorporated into British forces during the war or even before that time, or their living spouses. They used an intuitive, indigenously viable snowball data collection method, although they would not have described what they did in this way. Kachin recruits could recall vividly those with whom they had worked and fought alongside and they were able to bring former allies or their families into the research nexus. The local kinship system also contributed to this by providing a widely distributed channel for networking and communications. In addition, the project was the subject of great local interest and publicity. This meant there was a good chance that a significant majority of those still able to recount basic information were brought within its coverage through these wider networks, as well as the small monetary benefit and social recognition that could accrue. ${ }^{56}$

Clearly, these data are best suited to developing descriptive-level understandings, but the starting point must obviously be to try to determine what the population group might actually be so that one could try to describe from it. For it to be possible to make statements that might be generalized to a wider population, obviously the extent of that wider population has to be known. Therefore, questions such as 'How many Lisu recruits signed up to the colonial military before, during and after the Second World War?' could not be answered from these data. We know neither the extent to which any of the recruits were Lisu, nor how the term Lisu might function as a concept, nor the size of the population of which this would be a sample; nor could we even ask the question 'Why did they join?' The only population group that could be delineated with some sense of confidence would be that of Kachin men who had affiliated with Kachin volunteer forces during the Second World War after 1942. The population parameter of this group cannot be known with precision either, but it is possible to develop a workable upper figure. In addition, the characteristic variables of this population were not fully known even by the local researchers when they started collecting information, as this was a learning experience for them, too. However, the research helped them to delineate population characteristics and act to ensure that all characteristics were covered to the best of their ability by the use of extensive publicity within the Kachin community, snowball data collection and extensive travel to different regions around the country.

Brief service histories of almost 1,300 men were compiled, as well as of nine female nurses who joined with the Allied military machine in this region in various capacities during the Second World War (see Figure 2).$^{57}$ Of these, 1,106 records

56 Personal communications, Myitkyina, Hpauwung Tang Gun and CC Naw Ja, March 2002. See also Tang Gun Hpauwung, and Chyauchyi, Naw Ja, Lai Sai Tsa Ban Laman Na Jiwa Ni a Arawng Ningsang (place, publisher and year unknown).

57 These included two nurses with Gordon Seagrave's mobile military hospital. See G.S. Seagrave (1943), Burma Surgeon, W.W. Norton, New York. 


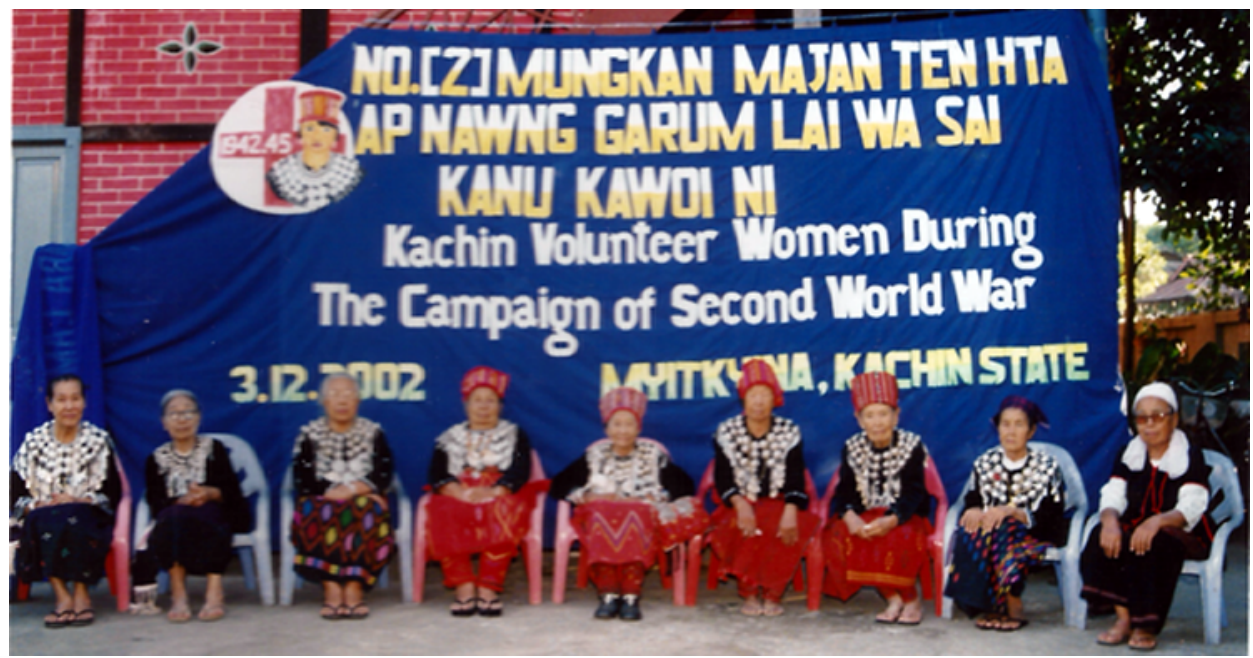

Figure 2. Women volunteers in the Second World War, Myitkyina 2002. Photo courtesy Lt Col Sam Pope.
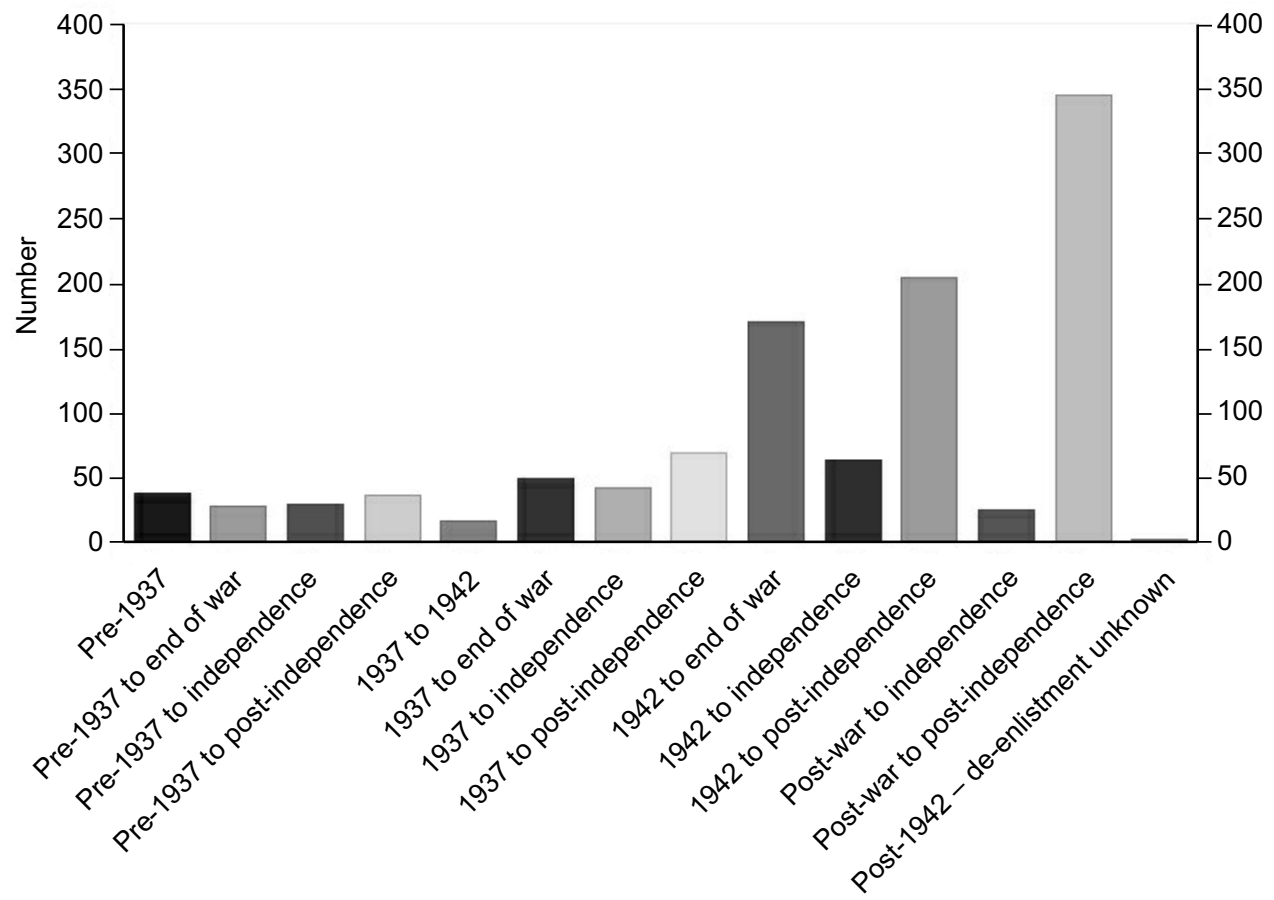

Service histories

Figure 3. Service histories of men in the dataset. 
were reliable enough for inclusion within the database developed as part of this secondary research. ${ }^{58}$ Of the 1,106 men included in this analysis, 37 had joined the army in the period before 1937 and left before that date, when the Burma Rifles were reorganized. This was a historically meaningful date to recode their service history, as it represented a new phase of imperial governance with the introduction of administrative structures to implement the formal separation of Burma from India, which also had implications for the army. It became a year in which attention focused critically upon military interactions with Kachin society, too. ${ }^{59}$ In addition, 16 men joined after 1937 but left by or in 1942, when the Kachin soldiers were told that they could return to their homes. This followed the Japanese invasion of Burma and the British evacuation, making it another viable date for coding service histories. Records of a further 369 men showed that their enlistment in the Kachin Rifles and other military structures such as the Union Military Police was only from 1945-48. We know that two Kachin Rifles battalions were founded following the Kandy Agreement and so we can state with some confidence that this figure is likely to be a meaningful number for making generalized comments about recruitment during 1945-48 in the Kachin Rifles. However, this is one area in which access to official records in the future may prove very helpful. ${ }^{60}$ In sum, we are left with reliable records for 684 men who joined the British military machine at different times, some before or during the war; yet all 684 in this group are coded by the fact that they had direct experience of fighting in the Second World War (see Figure 3).

We know that the reliability of data samples is not determined by the percentage of the sample size in relation to the population group, but rather by the confidence levels of the sample size, as these do not increase exponentially with larger and larger samples; a size is reached that is deemed large enough to make generalizations with higher or lesser confidence about precision. Estimates for a population group of the size that we might broadly expect of those who had associated with British military forces during the Second World War (between 10 and 13,000 would seem a reasonable figure, although probably on the high side) typically state that between 290 to 960 data samples would represent a valid, statistically meaningful set with confidence levels between $95 \%$ and $99 \%$. This would seemingly position the data sample used in this research well within the size likely to be appropriate for making generalizations about this population group as a whole, broadly in the range of $99 \%$, but with a 5\% margin of error. Perhaps the key issue, however, is that even if the data sample proved to be totally skewed and unrepresentative, it is a large enough group to warrant raising questions about the perceived homogeneity of Kachin military experience in colonial military structures, as outlined at the start of this paper. ${ }^{61}$ Yet the likelihood that this data sample is entirely unrepresentative is low, and even if it were so because of some totally unanticipated

58 Reliability was assessed largely through the internal coherence of the record presented. Where manual errors in recording had crept in, these were not adjusted unless additional information could justify this.

59 M. Sadan ((2010), 'Syphilis and the Kachin regeneration campaign, 1937-38', Journal of Burma Studies, Vol 14.

60 Mary Callahan's work is, of course, groundbreaking in this respect, and with time we can only hope that greater accessibility to military archives in Burma may in the long term provide clearer answers to many of these questions.

61 N. Blaikie (2003), Analysing Quantitative Data, SAGE Publications, London, Delhi, Thousand Oaks, CA, and Singapore. 
bias or flaw in the research method, it would not be entirely fatal to the primary arguments being presented. In sum, therefore, these materials constitute a potentially significant new form of data for generating new research questions and hypotheses around the issues previously outlined.

\section{Research questions: the demographics of recruitment}

Robert Taylor's statement that ethnic Kachin and Karen soldiers demonstrated their loyalty to the colonial order by remaining 'loyal to Britain in defeat' is clearly a subjective, qualitative one, the proven basis for which is not entirely clear. We cannot use these data to state categorically that Kachin recruits were or were not 'loyal'. ${ }^{62}$ However, we can use the data to explore some of the assumptions generated from Taylor's statement as a means of testing it. Most obviously, we can test the assumption that recruits in British forces before the war were those who were drawn back into fighting with Allied forces during the war (Taylor would say because of their loyalty). ${ }^{63}$ Beyond this, we can test whether many of these men went on to fill the ranks of the Kachin Rifles in the restructured military system established by the Kandy Agreement. On these grounds the historical argument is built that 'ethnic' soldiers after the war were essentially the same 'stock' as those who were in the colonial military before it, resulting in the representations that were detailed at length earlier. This paper tests these assumptions by outlining quantitatively a possible answer to one principal research question: to what extent were recruits in the Second World War in this data sample connected to colonial military structures before and/or after the war? While it is not possible to use these data to explain motivations and 'loyalties', they may alert us to whether current assumptions about these issues are rooted in less stable terrain than is typically assumed. By making a cautious generalization about the wider population group on the basis of the research findings, new insights may be had on these complex issues.

First, with reference to the data shown in Figure 3, it is clear that $63.7 \%$ of those Kachin men in the sample who volunteered to fight in the Second World War had no previous experience in colonial military forces. It might be argued that the data could be skewed by the greater age of those enlisting in the pre-war period, meaning that they would be more likely to be excluded from the research. However, this would assume that there was a standard recruitment age for Kachin men into colonial forces that operated at equal intervals across all the variables. When we look at the age of enlistment for all men in the data sample from all groups, we see that the pattern appears as in Figure 4, which profiles the population sample as a whole according to their age of enlistment. ${ }^{64}$ The optimum age for recruitment was clearly 18-19, with an obvious spike in the data being produced in line with this. This, of course, accords with general military practice in these matters in which young men are desired as recruits within the ranks, confirming them as operational in this setting. Following on from this, we can then identify whether

62 For a fuller discussion of this issue and further qualitative insights relating to this subject, see Sadan, supra note 1.

63 Taylor, supra note 2.

64 References to very young recruits often related to those who worked as porters or as menial workers rather than as arms-bearing volunteers. 


\section{South East Asia Research}

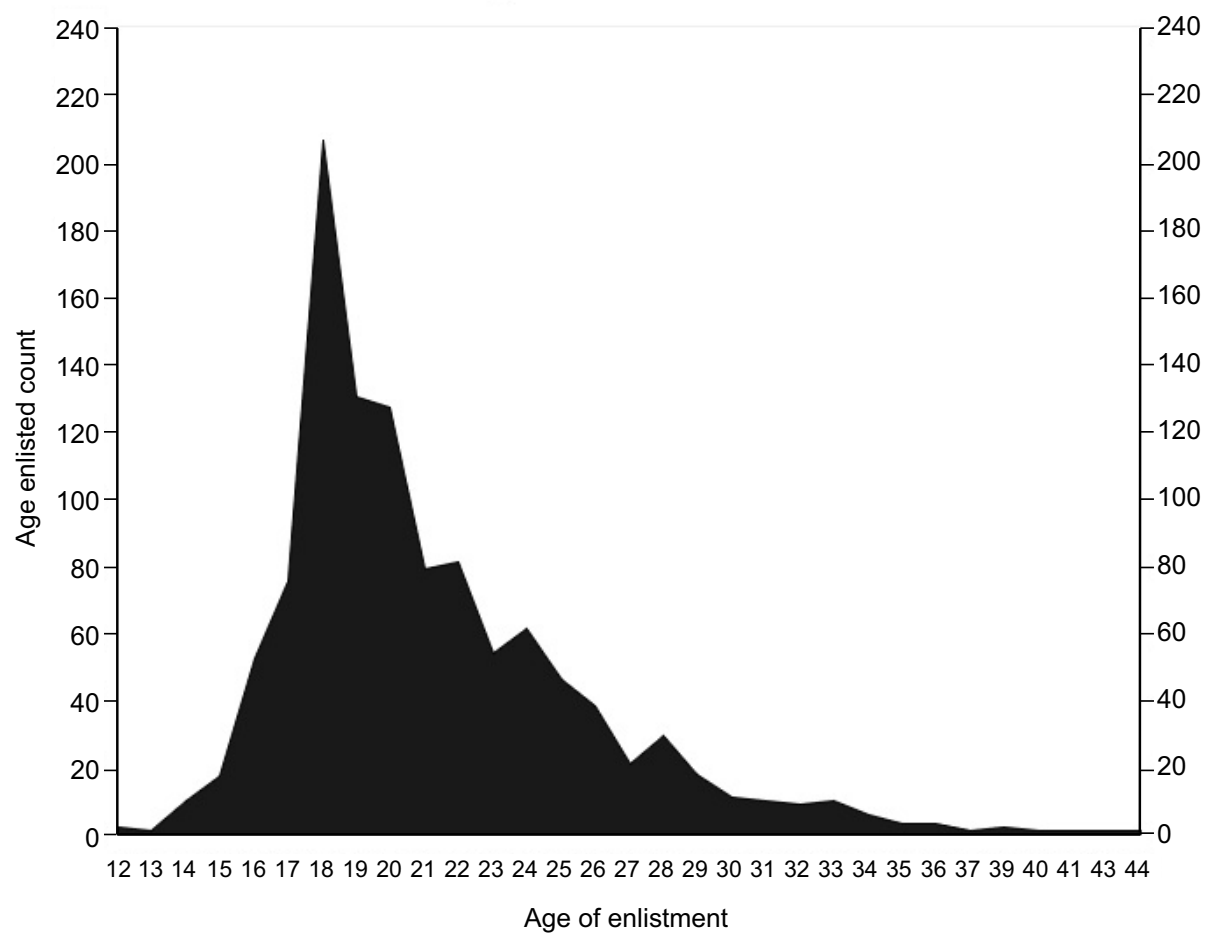

Figure 4. Enlistment age profile of men in the data sample.

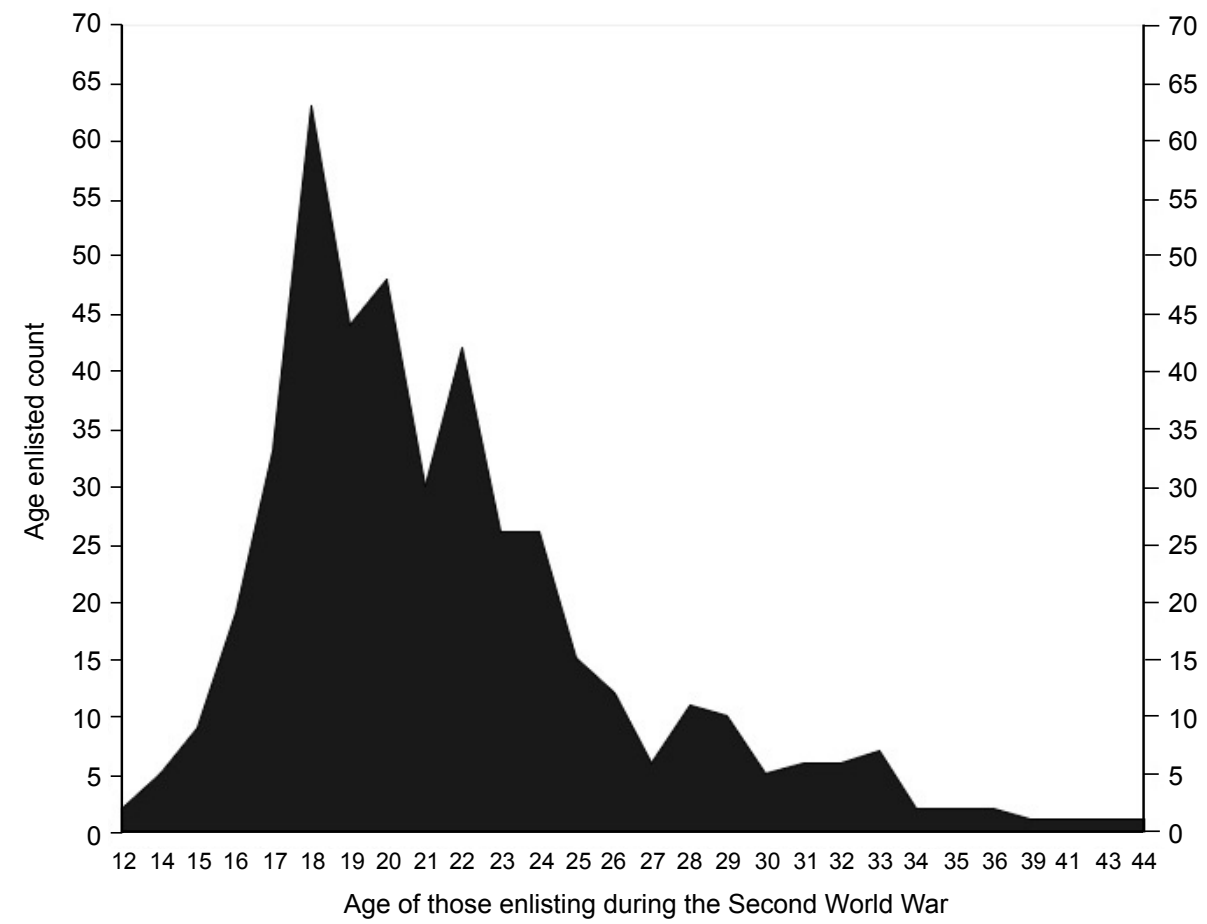

Figure 5. Enlistment age profile of men enlisting during the Second World War. 


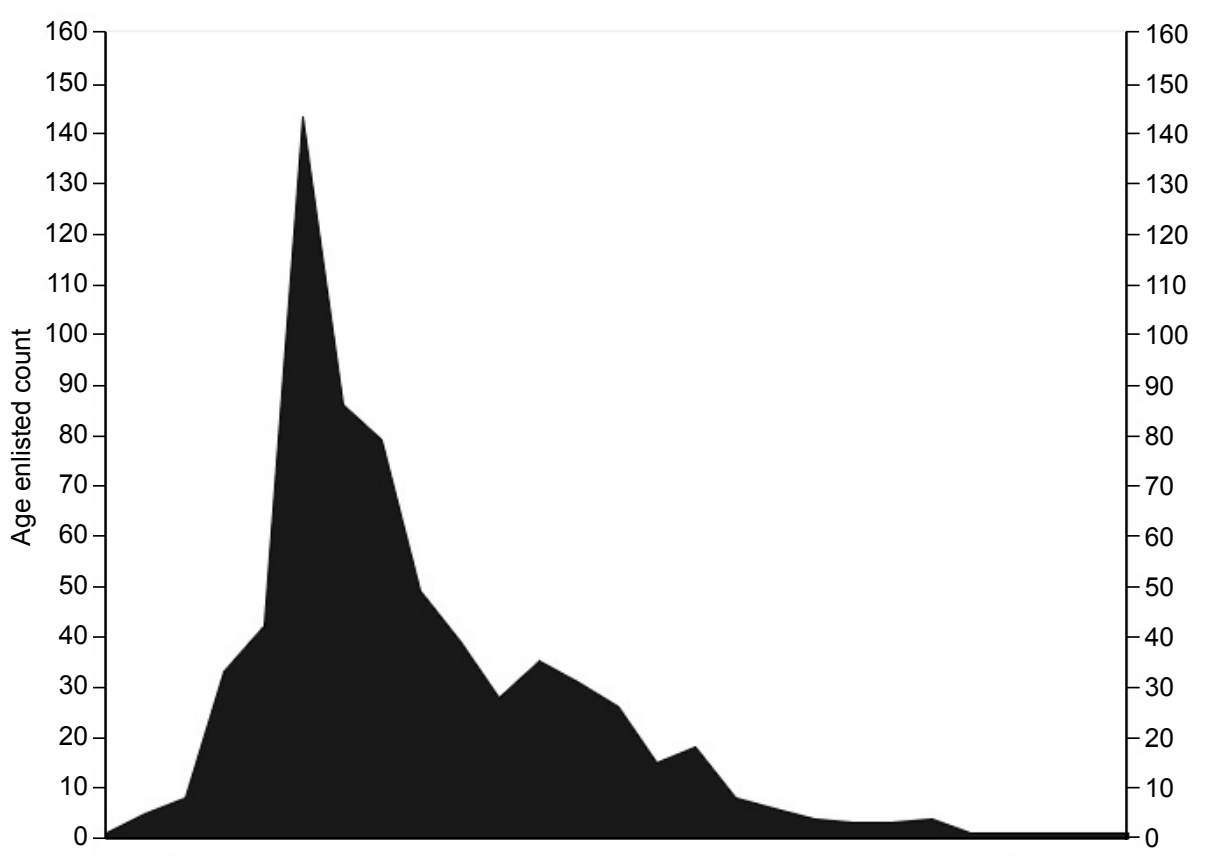

$\begin{array}{lllllllllllllllllllllllllll}13 & 14 & 15 & 16 & 17 & 18 & 19 & 20 & 21 & 22 & 23 & 24 & 25 & 26 & 27 & 28 & 29 & 30 & 31 & 32 & 33 & 34 & 35 & 36 & 37 & 39 & 40\end{array}$

Age of enlistment

Figure 6. Enlistment age profile of men in the data sample not recruited during the Second World War.

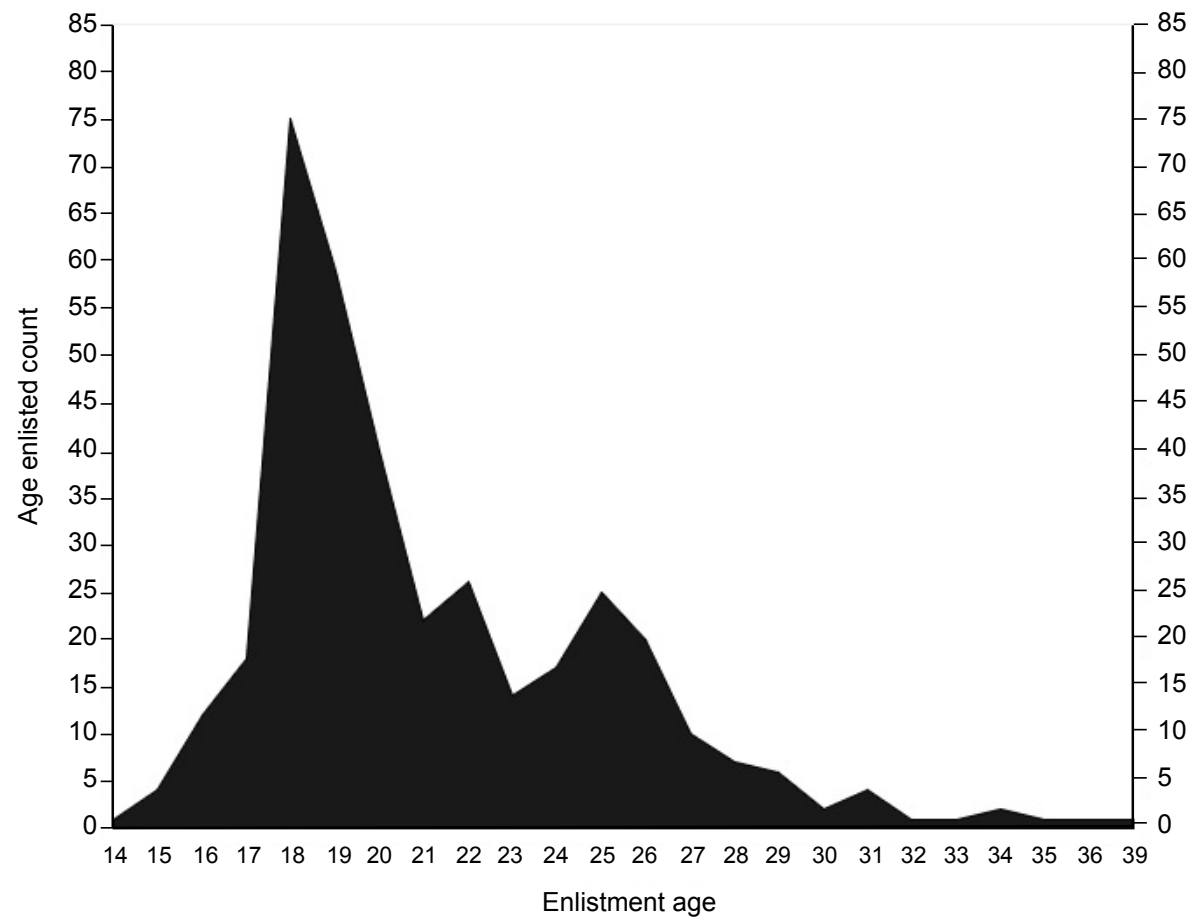

Figure 7. Enlistment age profile of those entering military service, 1945-48. 
the recruitment pattern for Second World War recruits followed this normative pattern or not.

Figure 5 shows the demographic pattern of those who volunteered for service during the Second World War, while Figures 6 and 7 show the age of those in the dataset who enlisted at other times, and those enlisting only after the war.

When we compare these line graphs, we see that the shape produced by mapping the ages of recruits in the Second World War (418 out of 436 had reliable age data) is quite distinctively skewed relative to that of other groups. Enlistment into wartime volunteer forces seems to have taken place across a wider and relatively older demographic group, as the tail stretches even into the mid-40s age group. This is perhaps only to be expected, given that normal recruitment practices would have been suspended in this emergency situation. However, significance should be attached to the more even span seen across the early to mid-20s age range too. This is important if we are to contest the idea that the demographic variance was simply a consequence of chronological skewing in the dataset. If we take 18 as the optimal age of recruitment into regular military structures, the minimum age that one would have to be to sign up before the war (1941 in this model) would be 19. To sign up before 1937, one would have had to have been no less than 23 years old in 1942 or at the date enlisted; 346 of these men, or $82.78 \%$ of those with reliable age data, fell within this range. These men were all entering military forces for the first time, yet the majority were of an age that they could have enlisted in the Burma Rifles or other political-military structures of the colonial state before the war if they had wanted to do so, but had clearly not done.

Significantly, none of these Second World War volunteers was required to take an oath of loyalty. ${ }^{65}$ We see here, therefore, that the assumption that most men fighting in the Kachin region were doing so out of prior loyalties or through previous military attachments is not supported by these data. Indeed, the fact that they had different objectives was even acknowledged by wartime military officers such as Ian Fellowes-Gordon, who recognized the local impetus of protecting their own homes and livelihoods as the war began to engulf this region. ${ }^{66}$ There was no financial incentive in this situation; many of the volunteers experienced extreme hardships, and the weak distribution capacities of the British forces in particular often meant that they were left without either munitions or stores for extended periods. ${ }^{67}$ In sum, we can state justifiably on this basis that most of the Kachin men fighting in the Second World War in this data sample were entirely new volunteers to the colonial and Allied military organizations operating in these areas; they had taken no oath of loyalty and they had no previous experience in the colonial military system. ${ }^{68}$ Many within this group could

65 Public Records Office [PRO]: Northern Combat Area Command: North Kachin Levies, 1943 Mar.-1944 Nov.: WO 203/118 - 92143. In a letter sent from the field dated 12 August 1944, Fellowes-Gordon stated that the levies were not bound by any oath of allegiance.

66 Fellowes-Gordon (1971), supra note 30.

67 PRO: Northern Combat Area Command: North Kachin Levies, 1943 Mar.-1944 Nov.: WO 203/ 118 - 92143. Fellowes-Gordon paints a grim picture of the travails that the levies had to endure and the negative view many of them took of the British military system that had failed to support them adequately, deficiencies that were highlighted by the relative strength of US levels of support in this zone of combat. He summarized, 'British prestige in 1942, despite the severe setback of the Burma campaign, was high in the Kachin Hills. Unfortunately, since that time it has dwindled.'

68 Public Records Office [PRO]: Northern Combat Area Command: North Kachin Levies, 1943 Mar.-1944 Nov.: WO 203/118 - 92143. 


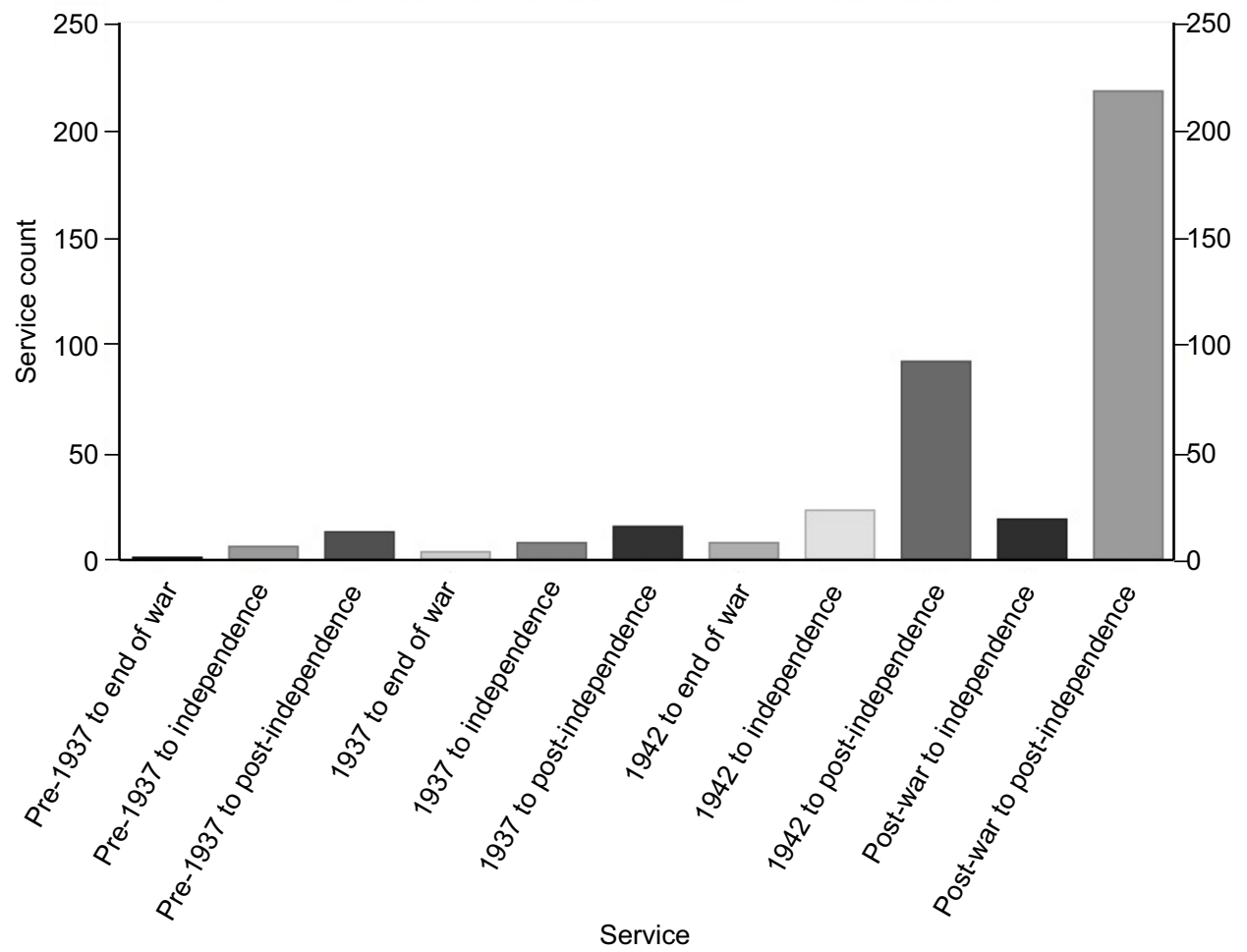

Figure 8. Service histories of men in the dataset signing up to join the Kachin Rifles.

have signed up to a military career in the colonial army, but they had not had chosen to do so. This is also borne out by other research into the difficult recruiting environment of this region in the last years before the war in which anti-colonialism was an ongoing reality, especially among the region's youth. ${ }^{69}$

A related issue, if we are to understand the demographics of the Kachin soldier and whether or not he should be considered a complex, changing societal figure or a historically homogenized, politically and emotionally monochrome one, is the extent to which involvement in the Second World War led to continued enlistment in the Kachin Rifles after the war. ${ }^{70}$ Figure 8 gives a clearer picture of this relationship among this population sample.

Of the 406 men who joined the Kachin Rifles before independence in 1948, and who were therefore technically recruits into colonial forces, 237 or $58.37 \%$ of them had no experience of any colonial military organization during or before the

Sadan, supra note 59.

70 Callahan, supra note 2, at pp 96-100. Ian Fellowes-Gordon also gives the impression that the Kachin Levies morphed wholesale into the Kachin Rifles in 1946. In plate 19 of his book, the photograph caption reads: 'The victory celebrations in Myitkyina, January 1946. The Governor of Burma, Sir Reginald Dorman-Smith, dedicates a Kachin Shrine. His body-guard is the new and proud "Kachin Rifles", nee "Kachin Levies".' This conflates the issue of dealing with the problem of demobilizing volunteers from military service in the war through the new military set-up, with the need to enlist regulars into the Kachin Rifles, which was determined by other factors as we have seen, and the inclusion of many new, young recruits. Fellowes-Gordon (1971), supra note 30, facing p 135. 
war. We see this also in Figure 7, where the recruitment pattern more closely resembles what we might expect in times of more regular and regulated recruitment practices not skewed by emergency policies or war; it reverts to a shape with a strong peak between the ages of 18 and 19. Of these men, 123 (or 30.3\%) had fought during the war and were then transferred to the Kachin Rifles. This may have been part of the compulsory process set up to ensure controlled demobilization of potentially disruptive military forces after the war. ${ }^{71}$ It is clear that most of those who joined the Kachin Rifles in this sample were again, therefore, wholly new recruits into military structures and constituted a new, youthful demographic group. Forty-six (or $11.33 \%$ ) had also enlisted in colonial forces before the war. What is interesting in this respect is that the majority of these figures with complex service histories bridging variables $-60.87 \%$ of them - transferred their loyalties across multiple military systems, be they pre-war colonial, wartime Allied, post-war colonial or post-colonial independence structures. This also included in some cases very long careers in military structures that were not ethnic nationality Kachin, but were state-controlled, such as the Union Military Police. The oldest of them had first entered the Military Police in 1899. These were career soldiers who equally do not fit into the stereotypical model outlined earlier.

Nonetheless, of the 387 of the recruits in the Kachin Rifles about whom we have reliable dates of enlistment, it is clear that, once again, the Kachin Rifles comprised in the main men who had enlisted only in the war, or else chose to sign up immediately after it. Many of these constituted a new group of 18-19-yearolds, who would have been too young to be enlisted during the war (Figure 9). Entering military service after the war, they entered into a framework in which it was becoming clear that they were joining what was likely to be the new national army of Burma, not that of the former colonial military power. While there was considerable debate and uncertainty about the nature of the new political order that might emerge up to early 1947, from the Panglong Agreement onwards it became increasingly clear that faith was being put in the promise that the Kachin state was to be an important, integral part of a new Union of Burma. ${ }^{72}$ Indeed, politicized youth groups were vital to the development of this strategy throughout the latter months of 1946, and this, of course, was the group from which the new ranks of the Kachin Rifles were also drawn. ${ }^{73}$ In sum, there is little in this population sample to support the notion that these young men were inevitably the inheritors of colonial loyalties or that their primary motivations in joining up to these new military structures could be assumed to be preserving colonial authority or the desire to subvert the Union before it had even begun.

One final element in the assumptions about the interaction between colonial and post-colonial military structures can be tested in this data sample. That is the degree to which all these previous experiences led to the creation of inflated ethnic armed groups, in this case the Kachin Independence Army, which was founded in 1961 but expanded in size markedly up to 1963 through a process of forced and voluntary recruitment. Do these data support the assumption that those who had

71 PRO: Northern Combat Area Command: North Kachin Levies, 1943 Mar.-1944 Nov.: WO 203/ $118-92143$.

72 See Sadan, supra note 1 for a fuller account of political discussions around this issue and the influence of politicized youth groups.

73 Ibid. 


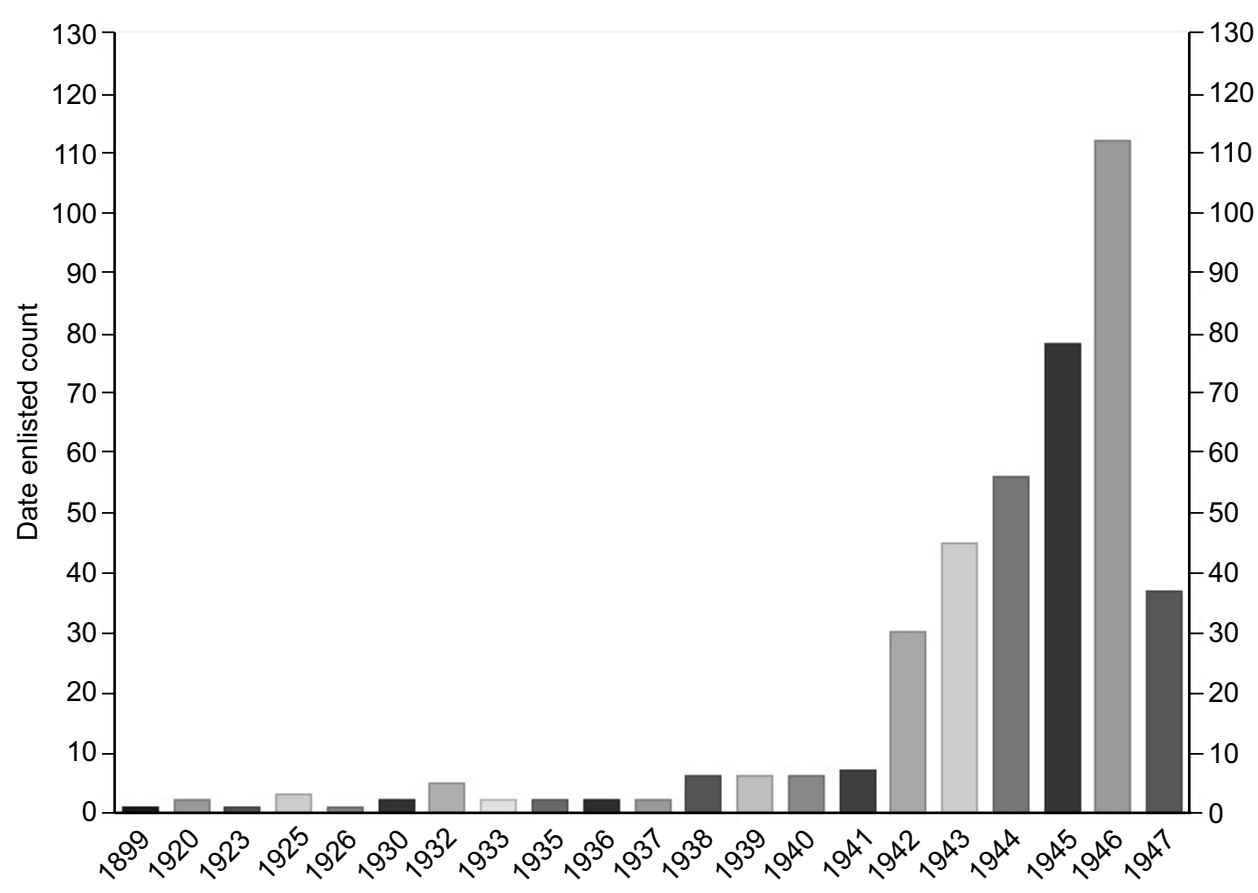

Date enlisted

Figure 9. Dates on which recruits who joined the Kachin Rifles originally enlisted.

fought in colonial forces at any period or in the Kachin Rifles in the independent state were those who now went on to fill the ranks of the KIA, creating this linear historical trajectory of military involvements that Taylor and others so neatly describe?

It is not presently possible to perform similar quantitative analysis on KIA recruitment data, but we can consider some other evidence in the data sample. Figure 10 presents the demobilization dates of all those in the sample who became recruits in the Kachin Rifles.

Figure 10 shows a correlation between what we might anticipate historically in terms of demobilization and what is shown to have occurred in practice, again suggesting more broadly that this data sample constitutes a reliable dataset from which we may with confidence make generalizations even about the wider population group. Figure 10 shows a steady rise in demobilization as independence approaches, at which time the controlled demobilization following the war was taking place. Following independence, demobilization reduces until a dramatic peak emerges abruptly at exactly the time that the KIA was founded and during its years of early expansion, coinciding with the military takeover of power by General Ne Win and a more aggressive stance towards the ethnic class-based structures in the national army. ${ }^{74}$ Of course, we cannot know from these data the reasons for

74 It is also frequently referenced by former soldiers that at this time they were subject to relocation, which would have resulted in them moving far from home. This was objected to strongly and seemed to reflect the disregard for the concerns of ethnic class-based recruits, as well as the increasing fear of the Burma Army that they constituted a fifth column. Such concerns were also expressed clearly in the Frontier Areas Commission of Enquiry by representatives of the military. India Office Records, British Library: M/4/2854 - General Papers Frontier Areas Committee of Enquiry, p 339 ff. 


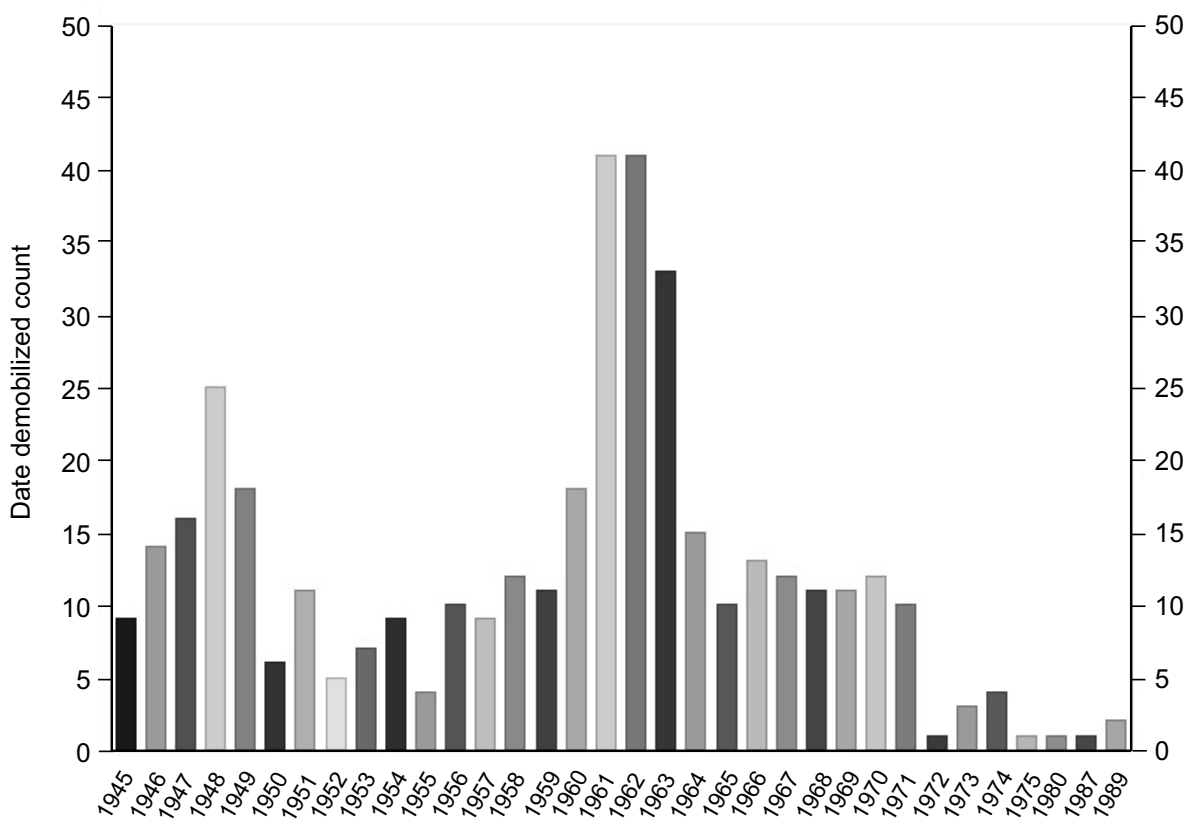

Year of demobilization from Kachin Rifles

Figure 10. Demobilization dates from the Kachin Rifles for those in the research dataset.

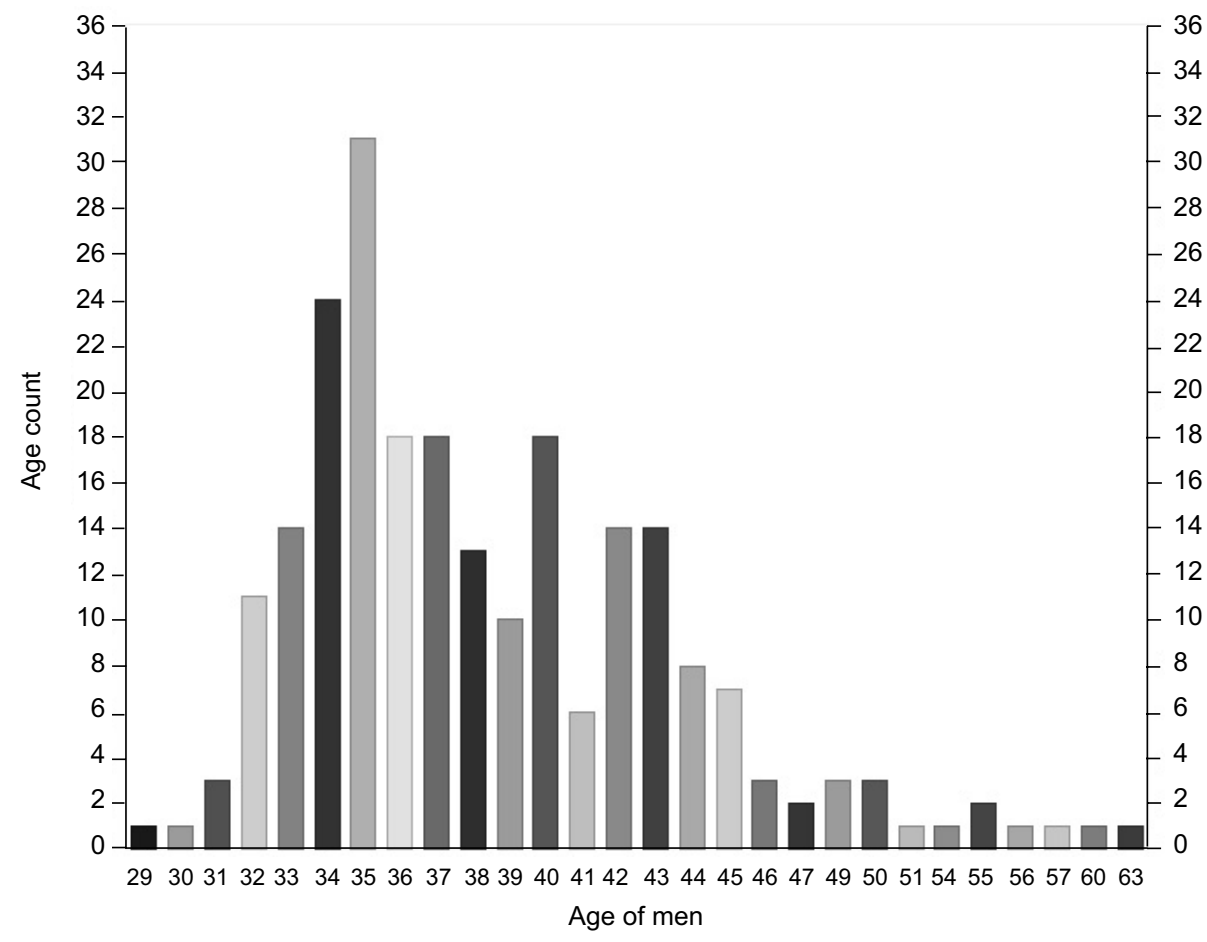

Figure 11. Age of men from data group leaving the military structures of the Union of Burma, 1960-63. 
this demobilization spike. However, we can hypothesize whether the men leaving the Kachin Rifles and any other Union organizations, such as the Union Military Police in the period 1961-63, would have fitted the normal demographic for recruitment into the new military structures established by the KIA, from what we have seen at previous transition points across multiple military structures.

Figure 11 shows that these men were of an age that was considerably beyond those who would typically have been recruited into military organizations. We have seen in the Second World War that there was a flattening out of the demographic curve somewhat, and a tendency in that particular emergency recruitment situation to enlist people of higher than optimum age, and this may have been replicated. However, although we cannot know from these data whether these men did transfer their loyalties to the KIA, it clearly was not a demographic group that would be desirable as providing the majority of the KIA's soldiers, for which the preferred age range would have been late teens to early twenties. Some of these men would definitely have been valuable for their skills and military knowledge, but the KIA could not have been formed of them alone. The evidence from this data sample does not, in fact, support the notion that the young men comprising the rank and file of the KIA would inevitably have been those who had fought on the side of the colonial order before, during or after the war. Neither, therefore, should we assume that they were driven by loyalty to this system through this earlier historical association: at each transition point we see new groups of young Kachin men being militarized in this population sample. Ultimately, we gain a sense of how simplistic these arguments have become over time in explaining the logic of linkages between colonial military systems and the manifestation of armed opposition to the Burmese state after 1961. This paper does not refute these linkages; it merely proposes that they have to be properly historicized and understood. It is evident that different demographic groups were key actors at different times, and we need to understand more clearly how the political discourses, expectations and frustrations of different periods contributed to the production of conflict and militarization. Only when we dismiss the simplifications outlined at the beginning of this section as a reasonable, totalizing account of these forces can we hope to move beyond the constraints of current discourse about the relationship of the Burmese centre to its peripheries. ${ }^{75}$ Only then can we also hope to understand fully the longer-term dynamics that have led to the re-emergence of violence across multiple generations.

\section{Conclusions and prospects}

There are, of course, many questions that an outside researcher might have liked to add to the questionnaire that provided the data for this research. However, perhaps one reason why it worked so well was precisely because of the lack of outside interference and intervention. The result was an internally coherent data sample that mapped on to local concerns in meaningful ways. The research method reflected local social realities, such as the inclusion of spouses and awareness of how the kinship system could operate to extend the reach of research. Furthermore, the research here represents only a small proportion of the ways in which

75 See Sadan, supra note 1 for a fuller discussion of how the discourse of religion has been transformed by the experience of long-term conflict in the post-independence state. 
these data could be analysed. There may also be possibilities in the future for extending this research into other militarized organizations. For example, the Kachin Independence Army maintains records of its recruits with some rigour. One day such records may perhaps be utilized to develop a deeper understanding of the social impact of the extended conflict in this region. They may provide us with insights into how military structures reflected social geographies or other demographic contexts. Such documentation presents one of the few forms of indigenously produced data through which we might be able to approach these issues quantitatively. Quantitative data are an essential prerequisite of description from which we may in turn develop more penetrating questions. The critical issue for researchers then becomes one of research ethics, in particular relating to the secondary use of datasets involving 'human informants'. One can only hope that if these issues cannot be resolved satisfactorily in the short to medium term, such materials may be preserved sufficiently to make them valuable data sources for future research. Preliminary research is still greatly to be desired to move understanding beyond currently constraining stereotypes and misplaced assumptions about the motivations and aspirations of those communities engaged in long-term resistance to national military governance.

Developing better understandings of the development of ethnic militarization in relation to efforts to create a national army in the late colonial state is also one area of research that is clearly of some relevance to current political discussions. The shape that a future national army in Burma will take will be very important as part of the effort to produce workable political solutions to the country's present ethnically framed dilemmas. Although to some observers it may seem no more than academic artifice, developing more detailed and contingent historical understandings of the participation of different communities in the conflicts of the Second World War is important in this process. The redesigned national army must deal directly with the consequences of past actions and consider anew the place held by ethnic class-based recruitment within the collective historical memory of the institution. These decisions are influenced not only by the ghost of the Burma Army's past and by its nationalist heritage as a liberator from foreign oppression, but by the continued imaginary of the supposed loyalty of non-Burmese soldiers to colonialism and their subsequent disloyalty to the national military institutions of independent Burma, which many commentators assume to have arisen from these origins. ${ }^{76}$ This paper suggests that we are still a long way from understanding these issues in any depth. Establishing the truth or otherwise behind some of these currently controlling ideas is important for shaping the perceptions of the past among those proposing solutions for the future. Insofar as they may also be part of any longer-term process of 'national conciliation', it is also important that they should be subjected to a more rigorous form of historical enquiry.

76 Such accounts do not acknowledge the continued, important role that non-Burman recruits have played in the national Burma Army for all of the post-independence period. Of these, the story of Chin recruitment is particularly notable, but has yet to be researched fully. 


\section{References}

Adas, Michael (1974), The Burma Delta: Economic Development and Social Change on an Asian Rice Frontier, 1852-1941, University of Wisconsin Press, Madison, WI.

Anderson, R. (2007), 'The biographical origins of Political Systems of Highland Burma', in F. Robinne, and M. Sadan, eds, Social Dynamics in the Highlands of Southeast Asia: Reconsidering Political Systems of Highland Burma by E.R. Leach, Brill, Leiden, pp 3-30.

Army and Military Pensioners Ex-Servicemen's Association, Bhamo, Jinghpaw Hpyen Dap Laba Laika (place, publisher and date unknown).

Aung-Myoe, Maung (2009), Building the Tatmadaw: Myanmar Armed Forces Since 1948, Institute of Southeast Asian Studies, Singapore.

Aung-Thwin, Michael (1985), 'The British "pacification" of Burma: order without meaning', Journal of Southeast Asian Studies, Vol 16, No 2, pp 245-261.

Bayly, C.A., and Harper, T. (2007), Forgotten Wars: The End of Britain's Asian Empire, Allen Lane, London.

Blaikie, N. (2003), Analysing Quantitative Data, SAGE Publications, London, Delhi, Thousand Oaks, $\mathrm{CA}$, and Singapore.

Brown, Ian (2005), A Colonial Economy in Crisis: Burma's Rice Delta and the World Depression of the 1930s, RoutledgeCurzon, London and New York.

Callahan, Mary P. (2003), Making Enemies: War and State Building in Burma, Cornell University Press, Ithaca, NY.

Charney, Michael W. (2009), A History of Modern Burma, Cambridge University Press, Cambridge.

Culas, C., and Robinne, F., eds (2010), Inter-Ethnic Dynamics in Asia: Considering the Other through Ethnonyms, Territories and Ritual, Routledge, London.

Dudink, S., Hagenamm, K., and Tosh, J., eds (2004), Masculinities in Politics and War: Gendering Modern History, Manchester University Press, Manchester.

Fellowes-Gordon, Ian (1958), Amiable Assassins, Hamilton, London.

Fellowes-Gordon, Ian (1971), The Battle for Naw Seng's Kingdom: General Stilwell's North Burma Campaign and its Aftermath, Cooper, London.

Hack, K., and Rettig, T., eds (2006), Colonial Armies in Southeast Asia, RoutledgeCurzon, London.

Hpauwung, Tang Gun, and Chyauchyi, Naw Ja, Lai Sai Tsa Ban Laman Na Jiwa Ni a Arawng Ningsang (place, publisher and year unknown).

Hpauyu, Nawng Ba, and Myithtoi, Gam Awng (2001), Mungkan Chyam Ai Jinghpaw Hpyen La Mazut Ni Mesopotamia (1917-19), May Offset, Yangon.

Jordt, I. (2007), Burma's Mass Lay Meditation Movement: Buddhism and the Cultural Construction of Power, Ohio University Press, Athens, OH.

Kramer, Tom (2007), The United Wa State Party: Narco-Army or Ethnic Nationalist Party? EastWest Center, Washington, DC, and Institute of Southeast Asian Studies, Singapore.

Leach, Edmund (1970), Political Systems of Highland Burma: A Study of Kachin Social Structure, Athlone Press, London.

Leach, Edmund (1961), Rethinking Anthropology, Athlone Press, London.

Lintner, Bertil (1990), The Rise and Fall of the Communist Party of Burma (CPB), Southeast Asia Program, Cornell University, Ithaca, NY.

Maran, La Raw (2008), 'The continuing relevance of E.R. Leach's Political Systems of Highland Burma to Kachin Studies', in Robinne, F., and Sadan, M., eds, Social Dynamics in the Highlands of Southeast Asia: Reconsidering Political Systems of Highland Burma by E.R. Leach, Brill, Leiden, pp 31-66.

Myihtoi, Gam Awng (2000), Subedar Major Myihtoi Naw a Ahtik Labau (place and publisher unknown).

Nemoto, Kei (2000), “The concepts of Dobama (“our Burma”) and Thudo-Bama ("their Burma") in Burmese nationalism, 1930-48', Journal of Burma Studies, Vol 5, pp 1-16.

Robinne, F., and Sadan, M. (2007), 'Reconsidering the dynamics of ethnicity through Foucault's concept of "spaces of dispersion"", in Robinne, F., and Sadan, M., eds, Social Dynamics in the Highlands of Southeast Asia: Reconsidering Political Systems of Highland Burma by E.R. Leach, Brill, Leiden, pp 299-308.

Sadan, M. (2013), Being and Becoming Kachin: Histories Beyond the State in the Borderworlds of Burma, The British Academy and Oxford University Press, Oxford.

Sadan, M. (2012), 'Cords and connections: ritual and spatial integration in the Jinghpaw Cultural Zone', in Blackburn, T., and Huber, S., eds, Origins and Migrations in the Extended Eastern Himalayas, Brill, Leiden, pp 253-274.

Sadan, M. (2007), 'Decolonizing Kachin: ethnic diversity and the making of an ethnic category', in Gravers, M., ed, Exploring Ethnic Diversity in Burma, NIAS Press, Copenhagen, pp 34-76.

Sadan, M. (2009), 'Ethnic minorities and political governance: the Myanmar situation', in Ghosh, L., ed, Minorities, Community Rights and Political Governance: South \& S.EAsian Scenario, Routledge, Abingdon, pp 151-179. 
Sadan, M. (2007), 'Historical photography in Kachin state: an update on the James Green Collection of photographs', South Asia: The Journal of the South Asia Studies Association of Australia, Special Issue: Northeast and Beyond: Culture and Change, pp 457-477.

Sadan, M. (2010), 'Syphilis and the Kachin regeneration campaign, 1937-38', Journal of Burma Studies, Vol 14, pp 115-149.

Seagrave, G.S. (1943), Burma Surgeon, W.W. Norton, New York.

Selth, A. (1986), 'Race and resistance in Burma, 1942-45', Modern Asian Studies, Vol 20, No 3, pp 483-507.

Smith, M. (1989), 'Burma and World War 2', Cultural Survival Quarterly, Vol 4, No 13.

Smith, Martin T. (1999), Burma: Insurgency and the Politics of Ethnicity, Zed Books, London.

South, Ashley (2011), Burma's Longest War: Anatomy of the Karen Conflict, Transnational Institute/ Burma Centre Netherlands, Amsterdam.

South, Ashley (2008), Ethnic Politics in Burma: States of Conflict, Routledge, Abingdon.

South, Ashley (2007), 'Karen nationalist communities: the "problem" of diversity', Contemporary Southeast Asia, Vol 29, No 1.

South, Ashley (2003), Mon Nationalism and Civil War in Burma: The Golden Sheldrake, RoutledgeCurzon, London.

Steinberg, David (2010), Burma/Myanmar: What Everyone Needs to Know, Oxford University Press, Oxford and New York.

Stoler, Ann Laura (2009), Along the Archival Grain: Epistemic Anxieties and Colonial Commonsense, Princeton University Press, Princeton, NJ.

Streets, H. (2004), Martial Races: The Military, Race and Masculinity in British Imperial Culture, 1857-1914, Manchester University Press, Manchester and New York.

Tambiah, Stanley Jeyaraja (2002), Edmund Leach: An Anthropological Life, Cambridge University Press, Cambridge.

Taylor, R.H. (2006), 'Colonial forces in British Burma: a national army postponed', in Hack, K., and Rettig, T., eds, Colonial Armies in Southeast Asia, Routledge, London and New York, pp 195209.

Taylor, R.H. (1973), Foreign and Domestic Consequences of the KMT Intervention in Burma, Southeast Asia Program, Cornell University, Ithaca, NY.

Taylor, R.H. (1982), 'Perceptions of ethnicity in the politics of Burma', Southeast Asian Journal of Social Sciences, Vol 10, No 1, pp 7-22.

Taylor, R.H. (1987), The State in Burma, C. Hurst, London.

Tegenfeldt, H.G. (1974), A Century of Growth: The Kachin Baptist Church of Burma, William Carey Library, South Pasadena, CA.

Thawnghmung, Ardeth Maung (2011), Beyond Armed Resistance: Ethnonational Politics in Burma (Myanmar), Policy Studies No 62, East-West Centre, Honolulu, HI.

Thawnghmung, Ardeth Maung (2008), The Karen Revolution in Burma: Diverse Voices, Uncertain Ends, Institute of Southeast Asian Studies, Singapore.

Thompson, Julian (2009), Forgotten Voices of Burma: The Second World War's Forgotten Conflict, Ebury Press in association with the Imperial War Museum, London.

Walton, M. (2008), 'Ethnicity, conflict and history in Burma: the myths of Panglong', Asian Survey, Vol 48, No 6, pp 889-910.

Walton, M. (2013), "The "wages of Burman-ness": ethnicity and Burman privilege in contemporary Myanmar', Journal of Contemporary Asia, Vol 43, No 1, pp 1-27. 